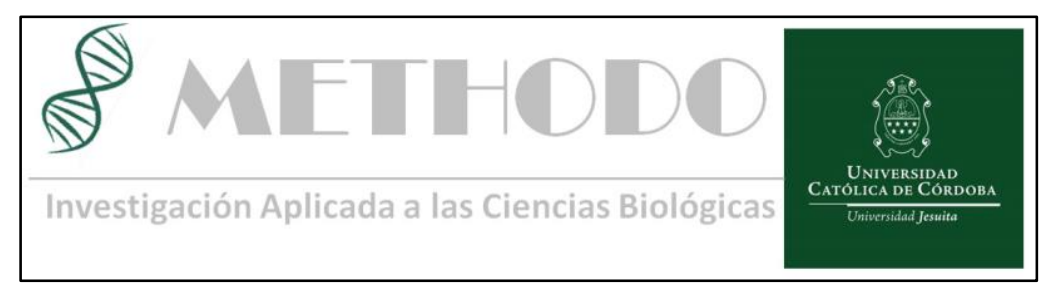

ARTICULO ORIGINAL Methodo 2017;2(2):49-51 DOI: $10.22529 / \mathrm{me} .2017 .2(2) 03$

Recibido 03 Dic 2016 | Aceptado 10 Abr 2017 | Publicado 30 Jn 2017

\title{
Caracterización nutricional del paciente con síndrome metabólico: resultados preliminares*
}

\section{Nutritional characterization of the patient with metabolic syndrome: preliminary results*}

${ }^{*}$ Resumen deTrabajo Presentado en las XIII Jornadas de Investigación de la Clínica Universitaria Reina Fabiola- Diciembre de 2016

Bertorello $\mathrm{N}^{1}$, Lerda $\mathrm{D}^{2}$, Chamale $\mathrm{E}^{3}$, Mondino $\mathrm{R}^{3}$, Defagó $\mathrm{M}^{3}$.

\section{RESUMEN}

Introducción: el síndrome metabólico (SM) es una entidad clínica con alteraciones vasculares y metabólicas que predisponen a la enfermedad cardiovascular (ECV). El estado nutricional es un factor predominante en la evolución del SM y el riesgo de $\mathrm{ECV}$.

Objetivo: analizar el estado nutricional a través de indicadores antropométricos y alimentarios en pacientes con SM.

Métodos: estudio observacional, de corte transversal. Participaron 41 personas de ambos sexos (20 hombres y 21 mujeres), entre 30 y 60 años, que asistieron a consulta ambulatoria del Servicio de Cardiología y Clínica Médica de la Clínica Universitaria Reina Fabiola (CURF) y del Servicio de Cardiología No Invasiva del Hospital Nacional de Clínicas (HNC), durante el periodo 2015-2016. Se realizó toma de indicadores antropométricos para determinar el estado nutricional (índice de masa corporal o IMC), circunferencia de cintura (CC), presión arterial sistólica (PAS) y diastólica (PAD). Las variables alimentarias incluidas fueron valor calórico total (VET), consumo de colesterol (CCol) y consumo de sodio (CS). El estudio cuenta con la aprobación del Comité de Ética del CURF y HNC. Para estimar el VET, el consumo de colesterol y de sodio se utilizó el programa informático Interfood v.1.3. El análisis de los datos se llevó a cabo con el programa InfoStat. Para analizar si existían diferencias por sexo, se utilizó el test de Wilcoxon para variables continuas y Kruskal Wallis para las categóricas.

Resultados: el 93\% de los pacientes presentaron exceso de peso (el 61\% con IMC superior a $30 \mathrm{~kg} / \mathrm{mts} 2)$. En relación a CC, el $75 \%$ de las mujeres y $86 \%$ de hombres presentaron riesgo cardiovascular muy aumentado. La media de PAS fue $131,18 \pm 18,96 \mathrm{mmHg}$ y la de PAD fue $79,88 \pm 12,29 \mathrm{mmHg}$. El VET fue $2828,45 \pm 1255,42 \mathrm{Kcal}$, el consumo

Revista Methodo: Investigación Aplicada a las Ciencias Biológicas. Facultad de Medicina. Universidad Católica de Córdoba. Jacinto Ríos 571 Bo Gral. Paz. X5004FXS. Córdoba. Argentina. Tel.: (54) 351 4517299 / Correo: methodo@ucc.edu.ar / Web: methodo.ucc.edu.ar | ARTICULO ORIGINAL Methodo 2017;2(2):49-51 
Bertorello N, Lerda D, Chamale E, Mondino R, Defagó M. Caracterización nutricional del paciente con síndrome metabólico: resultados preliminares promedio de colesterol fue 380,09 $\pm 191 \mathrm{mg}$ (DBP). Included food variables were total y el de sodio fue $2072,26 \pm 1195,44 \mathrm{mg}$, siendo estas ingestas superiores a las recomendadas. Al analizar las comparaciones por sexo, no se encontraron diferencias estadísticamente significativas para las variables en estudio.

Conclusión: estos resultados preliminares resaltan el perfil de riesgo para el desarrollo de ECV de los pacientes con SM. Se necesita continuar profundizando el estudio de estas poblaciones, para aportar evidencia que contribuya a la promoción de hábitos saludables y la prevención de patologías crónicas vinculadas a la alimentación y nutrición.

\section{ABSTRACT}

Introduction: the metabolic syndrome (MetS) is a clinical entity with vascular and metabolic alterations that predispose a cardiovascular disease (CVD). Nutritional status is a predominant factor in the evolution of MetS and risk of CVD.

Objetive: Analyze the nutritional status through of anthropometric and food indicators in patients with MetS.

Methods: Observational studie, crosssectional. 41 people of both sex participated (20 man and 21 woman), among 30 and 60 years old, who attended outpatient consultation of Cardiology Service and Medical Clinic of Reina Fabiola University Clinic (RFUC) and Non-Inavasive Cardiology Service of National Hospital of Clinics (NHC), during the period 2015-2016. energy value (TEV), cholesterol intake (CoIC) and sodium intake (SC). The study has the approval Ethics Committee of RFUC and NHC. To estimate TEV, cholesterol and sodium intake was used computer program Interfood v.1.3. The analysis of the data was carried out with the InfoStat program. To analyze if there differences by sex, the Wilcoxon test for continuous variables and Kruskal Wallis for categorical variables were used.

Results: $93 \%$ of the patients presented overweight $(61 \%$ with BMI higher 30 $\mathrm{kg} / \mathrm{m} 2)$. In relation $\mathrm{WC}, 75 \%$ of the women and $86 \%$ of men showed highly increased cardiovascular risk. The mean of BSP was $131,18 \pm 18,96 \mathrm{mmHg}$ and SBP was $79,88 \pm 12,29 \mathrm{mmHg}$. The TEV was $2828,45 \pm 1255,42 \mathrm{Kcal}$, average intake of cholesterol was $380,09 \pm 191 \mathrm{mg}$ and the sodium was $2072,26 \pm 1195,44 \mathrm{mg}$, being these higher intakes to those recommended. When analyzing comparisons by sex, no statistically significant differences were found for the variables in study.

Conclusions: these preliminary results highlight the risk profile for the development of CVD of the patients with MetS. It is necessary to continue to deepen the study of these populations, to provide evidence that contributes to the promotion of healthy habits and the prevention of chronic diseases linked to food and nutrition.

Anthropometric measure were taken to determine nutritional status, body mass index or (BMI), waist circumference (WC), systolic and diastolic blood pressure (SBP) 
Bertorello N, Lerda D, Chamale E, Mondino R, Defagó M. Caracterización nutricional del paciente con síndrome metabólico: resultados preliminares

Palabras claves: SINDROME METABOLICO, ENFERMEDAD CARDIOVASCULAR, ESTADO NUTRICIONAL

Keywords: METABOLIC SYNDROME, CARDIOVASCULAR DISEASE, NUTRITIONAL STATUS

${ }^{1}$ Universidad Católica de Córdoba, Argentina. Clínica Universitaria Reina Fabiola, Servicio de Nutrición. ${ }^{2}$. Servicio de Biología Molecular. ${ }^{3}$. Servicio de Clínica Médica. Correspondencia: Natalia Bertorelo Servicio de Nutrición- Clínica Universitaria Reina Fabiola. Oncativo 1248 -X5004FHP- Córdoba, Argentina. email: natybertorello@hotmail.com 